Idawu Yakubu Suleiman ${ }^{*}$, Adams Mohammed Sani ${ }^{1}$, Ogheneme Ogheneblorhie Clifford ${ }^{2}$

${ }^{1}$ University of Nigeria, Department of Metallurgical and Materials Engineering, Nsukka, Nigeria; ${ }^{2}$ Department of Mechanical Engineering, Waziri Umaru Federal Polytechnic, Birnin Kebbi, Nigeria
Scientific paper

ISSN 0351-9465, E-ISSN 2466-2585 UDC:691.714: 665.7.038.5: 620.193.4 doi: $10.5937 /$ zasmat2003220S

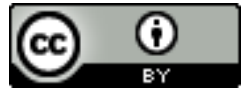

Zastita Materijala 61 (3) 220 - 228 (2020)

\title{
Characterization and corrosion behaviours of AISI 316 in hydrochloric environment at various concentrations
}

\begin{abstract}
Characterization and corrosion behaviours of austenitic stainless steel (AISI 316) types at various concentrations of hydrochloric acid solutions were investigated in relation to its pitting corrosion resistance. Both gravimetric-weight loss and potentiodynamic polarization were used for the investigations. The AISI 316 was characterized by $X$-ray fluorescent (XRF). The characterization of the coupon before and after the corrosion test in various concentrations was done using scanning electron microscopy (SEM). The temperature, acid concentration and time were varied in the range of $30-60^{\circ} \mathrm{C}$ at $10^{\circ} \mathrm{C}$ interval, $0.5-2 \mathrm{M}$ at $0.5 \mathrm{M}$ interval and 1 to 6 day at 1day interval, respectively. The XRF revealed some important elements in the AISI 316 such as (Cr, Ni, Mn, Si, $C, S, P$ etc) which confirmed the materials to AISI 316. The weight loss results revealed that the corrosion rate decreased with increase in exposure time from day 1 to day 6 . The corrosion rate of the AISI 316 increased with increase in temperature, severe to pits formation and growths with increase in concentration of acid from $0.5-2 \mathrm{M}$. The corrosion rate of AISI 316 increases with increase in acid concentrations. The Tafel results also revealed that both anodic and cathodic sites were shifted with the lowest corrosion resistance occurring at $0.5 \mathrm{M}$ of $\mathrm{HCl}$. The SEM of the coupons in the presence of acid revealed pits formation, growths and pitted AISI 316 surfaces. The results obtained from the weight loss, Tafel and characterization were also in good agreement.
\end{abstract}

Keywords: Austenitic AISI 316, Characterization, Corrosion Behavior, Pitting, Resistance, $\mathrm{HCl}$ solution, Tafel.

\section{INTRODUCTION}

The world demand for fossil fuels is still growing even though alternatives to such energy are currently being sought out globally. The consumptions of oil and natural gas account for over $60 \%$ of all global energy demands. It is obvious that the conventional method of extracting fossil fuels will not cease within the next few decades [1]. For years, corrosion has been a major problem in various industries especially in oil and gas and has caused approximately $80-90 \%$ failures in this sector [2].

\footnotetext{
${ }^{*}$ Corresponding author: Idawu Yakubu Suleiman

E-mail: idawu.suleiman@unn.edu.ng

Paper received: 15. 06. 2020.

Paper accepted: 10. 07. 2020.

Paper is available on the website:

www.idk.org.rs/journal
}

Corrosion occurs in different forms in structures made of steels during service in various environments. These forms of corrosion can be intergranular, pitting, sulphide stress cracking, and stress corrosion cracking. The consequences of these forms of corrosion are obvious, varying from huge material losses to unhealthy environment [3]. However, corrosion cannot be avoided completely, but it can be controlled and prevented by using suitable methods such as cathodic protection, anodic protection, metallic coating, alloying, using inhibitors combinations thereof have been successfully developed to extend the service lifespans of these structures in such corrosive environments [4].

The corrosion behaviours of stainless steel and other metals in acidic environments has been studied by many researchers. Austenitic stainless steels have been used successfully in many applications in both acidic and marine environ- 
ments [5-10]. Stainless steels are widely known which have been applied in various industries and environments. However, stainless steel (AISI 316) is the most common material used in a severe corrosive environment such as chloride, hydrochloric acids.

The stainless steel 316 is being classified as low-carbon austenitic stainless steel. The corrosion resistance of this stainless steel is classified as fair to good in various environments and expensive materials [11]. Austenitic stainless steels have a wide spectrum of resistance to corrosion by chemical environment due to the formation of protective passive film on its surface. This film is very thin, essentially transparent and self- healing. If it is damaged mechanically or chemically, it will reform very rapidly [12]. However, the passive films are susceptible to breakdown in the presence of chloride ion, causing pitting corrosion. Pitting corrosion being classified as very dangerous threat and produces pit which looks small on surface but propagate deep inside the metals. This type of corrosion is considered more harmful than uniform attack. The corrosion rate of pitting corrosion is 10 100 times faster than uniform corrosion [13].

Therefore, the aim of this work is to characterrize and determine the corrosion resistance of AISI 316 in different concentrations $(0.5 \mathrm{M}, 1 \mathrm{M}, 1.5 \mathrm{M}$, and $2 \mathrm{M}$ ) of hydrochloric acid and temperature between $30-60^{\circ} \mathrm{C}$ solutions using weight loss and potentiodynamic measurement test.

\section{EXPERIMENTALDETAIL}

\subsection{Materials}

The AISI 316 coupon used for this study was oobtained from a steel manufacturer company in Port Harcourt, Rivers State. The chemical composition analysis conducted on the sample was carried at Spectro Ametek, Materials Analysis Division, Lagos.

\subsection{Hydrochloric acid Solutions}

$0.5 \mathrm{M}$ hydrochloric acid was prepared by using the following equation:

$$
C_{1}=\frac{\% \text { purity of acid } x \text { density } x 10}{\text { molar mass of acid }}
$$

Where: \% purity of $\mathrm{HCl}$ acid $=37 \%$

Density of $\mathrm{HCl}=1.19 \mathrm{~g} / \mathrm{cm}^{3}$ and molar mass of acid $=36.46 \mathrm{~g} / \mathrm{mol}$

Thus, the concentration of stock from which the $0.5 \mathrm{M}$ hydrochloric acid and solution was prepared from is $12.08 \mathrm{M}$.

The quantity (volume) of the stock needed is then estimated by using the relation:

$$
C_{1} V_{1}=C_{2} V_{2}
$$

Where:

$\mathrm{C}_{1}=$ concentration of the stock,

$\mathrm{C}_{2}=$ the required morality of the acid $(0.5 \mathrm{M})$,

$\mathrm{V}_{1}=$ volume of stock solution needed to prepare the $0.5 \mathrm{M}$ acid and

$\mathrm{V}_{2}=$ volume of acid required $\left(1000 \mathrm{~cm}^{3}\right)$

$$
V_{1}=\frac{C_{2} V_{2}}{C_{1}}
$$

Therefore, about $41.5 \mathrm{~cm}^{3}$ of the stock was made up to $1000 \mathrm{~cm}^{3}$ in a litre standard flask to obtain the $0.5 \mathrm{M}$ concentration of $\mathrm{HCl}$ acid solution. The same procedures were used in producing $1 \mathrm{M}$, $1.5 \mathrm{M}$ and $2 \mathrm{M}$ concentrations respectively. All the test solutions used in the work were based on molarity and prepared from the above chemicals and conductivity water.

\subsection{Samples Preparation}

All specimens were mechanically polished to a mirror like finish using emery papers with increasing grit sizes $(100,180,400,500,600,800$, 1000 ), and degreased using acetone, before start the experiments. Austenitic stainless steels samples were cut into $1 \mathrm{~cm} \times 1 \mathrm{~cm}$ plates and later washed, dried and stored in a desiccator for the weight loss analyses.

\subsection{Weight Loss Measurements}

The weight loss experiments were carried out in accordance with the methods reported elsewhere [14-18]. Previously polished and degreased specimens of size $20 \mathrm{~mm}$ by $10 \mathrm{~mm}$ coupons were used for weight loss studies. Already-weighed specimens were separately immersed in 500 milliliters $(\mathrm{ml})$ of $0.5 \mathrm{M}, 1 \mathrm{M}, 1.5 \mathrm{M}$ and $2 \mathrm{M} \mathrm{HCl}$ solutions for $1,2,3,4,5$ and 6 days respectively. After the elapsed time, the specimens were taken out, washed, dried and reweighed. All the experiments were performed in triplicate, and average values were recorded. Seventy-two (72) samples were used and three samples were withdrawn every day for six (6) days. The experiment was carried out at four different temperatures of $30,40,50$, and $60^{\circ} \mathrm{C}$. From the measured weight loss data, the corrosion rates $(\mathrm{m} / \mathrm{y})(\mathrm{CR})$ were calculated using Equation $4[19,20]$ :

$$
C R=\frac{534 W}{D A T}, m p y
$$

Where W, D, A and T were units of milligrams, grams per cubic centimeter, square inches and hours respectively. 


\subsection{Potentiodynamic polarization studies}

The potentiodynamic polarization studies were carried out with a three electrode configuration. The specimens were embedded in epoxy resin and the exposed surface area of the AISI 316 working electrode was $1.24 \mathrm{~cm}^{2}$. The working surface area was subsequently ground with grinding papers from 600 down to 1800 grit, cleaned by distilled water and ethanol. The solutions of $0.5 \mathrm{M}-2 \mathrm{M} \mathrm{HCl}$ were prepared by dilution of an analytical reagent grade with doubly distilled water. Potentiodynamic polarization measurements were done using an Autolab potentiostat (PGSTAT30 computer controlled) with the General Purpose Electrochemical Software (GPES) package version 4.9. Potentiodymamic anodic and cathodic polarization curves were obtained with a scan rate of $2 \mathrm{mv} / \mathrm{s}$ in the potential range from -0.2 to $-0.8 \mathrm{mv}$ relative to the corrosion potential (Ecorr). Values of the corrosion current density $\left(I_{\text {corr }}\right)$ were obtained by extrapolation of the cathodic branch of the polarization curve back to Ecorr. From the polarization curves, Tafel slopes, corrosion potential and corrosion current were then calculated. All the tests were performed at ambient temperature $\left(30^{\circ} \mathrm{C}\right)$ in a static solution [21].

\subsection{Characterization of the Coupons}

The AISI 316 surface was prepared for SEM studies by taking the specimens from each concentration $(0.5,1,1.5$ and $2 \mathrm{M})$ at the optimum concentrations of the acid. The AISI 316 specimens were then washed with distilled water, dried and analyzed using SEM. A Philips model XL30SFEG scanning electron microscope was used for the surface analysis [22].

\section{RESULTS AND DISCUSSION}

\subsection{Chemical Composition of the Coupon}

The chemical composition analysis conducted on AISI 316 coupon used for this study was carried out at Spectro Ametek, Materials Analysis Division, Lagos. The composition of metal sample in weight $\%$ are presented in table 1 while the rest is iron.

\section{Table 1. Chemical composition of AISI 316}

Tabela 1. Hemijski sastav AISI 316

\begin{tabular}{|c|c|c|c|c|c|c|c|c|c|c|}
\hline Grade & $\mathrm{Cr}$ & $\mathrm{Mn}$ & $\mathrm{Mo}$ & $\mathrm{S}$ & $\mathrm{Ni}$ & $\mathrm{N}$ & $\mathrm{Si}$ & $\mathrm{V}$ & $\mathrm{P}$ & $\mathrm{C}$ \\
\hline AISI 316 & 18.20 & 1.24 & 0.137 & 0.008 & 8.28 & 0.052 & 0.500 & 0.0913 & 0.033 & 0.043 \\
\hline
\end{tabular}

\subsection{Weight Loss and Potentiodynamic Polarization Measurements}

\subsubsection{Effect of time}

Weight loss measurements were performed on AISI 316 coupons immersed in $0.5,1,1.5$, and $2 \mathrm{M}$ $\mathrm{HCl}$ solutions at different temperatures $30{ }^{\circ} \mathrm{C}$ for 6 days were carried out. Figure 1 presented variation in corrosion rate against exposure time for AISI 316 immersed in $0.5 \mathrm{M} \mathrm{HCl}$. It was observed that there was decrease in corrosion rate as exposure time increases [25]. This is because there was no space for direct contact between metal surface and corrosive ions by corrosion products and excess of cations near the metal surface as reaction proceeds. This is also in consonance with findings of [26].

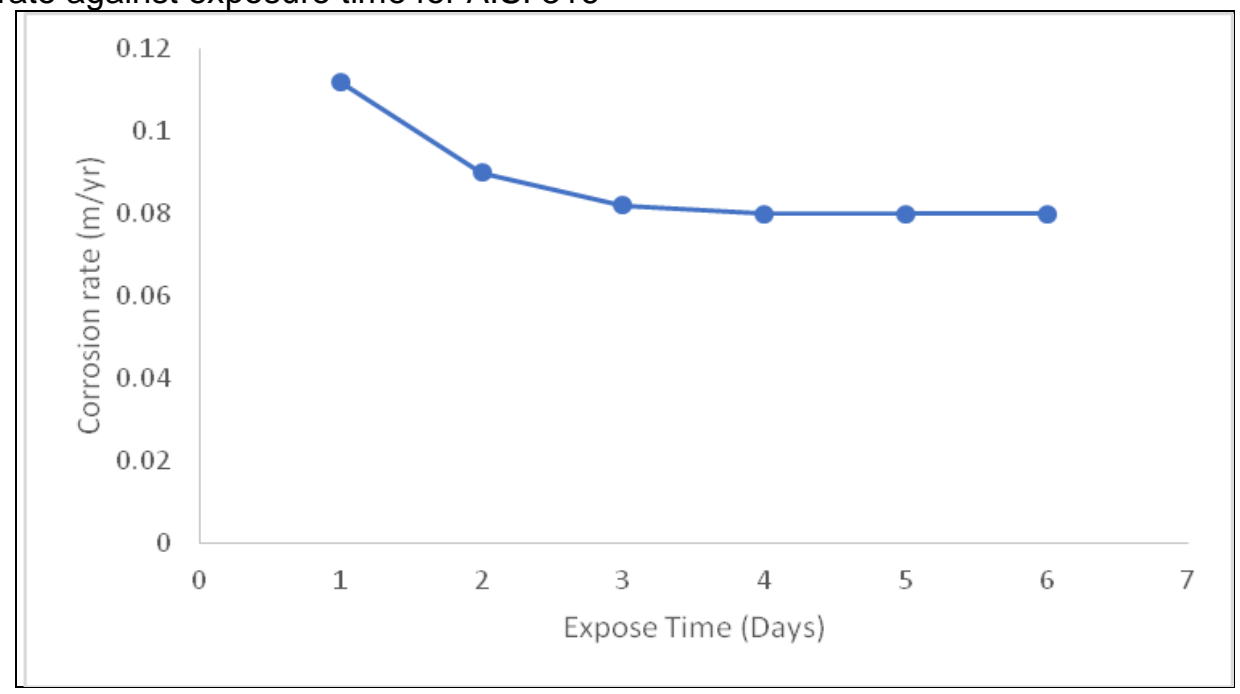

Figure 1. Variation of corrosion rate against exposure time for AISI 316 immersed in $0.5 \mathrm{M} \mathrm{HCl}$

Slika 1. Varijacija brzine korozije u odnosu na vreme izlaganja za AISI 316 uronjenog u 0,5M HCl 


\subsubsection{Effect of Concentrations}

Figure 2 shows an increase in corrosion rate as the concentration of the $\mathrm{HCl}$ increases from 0.5 $2 \mathrm{M}$. The results also show a corrosion rate of 0.2 $\mathrm{m} /$ year at $0.5 \mathrm{M}, 0.08 \mathrm{~m} / \mathrm{year}$ at $1 \mathrm{M}, 0.09 \mathrm{~m} / \mathrm{year}$ at $1.5 \mathrm{M}$, and $0.112 \mathrm{~m} / \mathrm{year}$ at $2 \mathrm{M}$ of $\mathrm{HCl}$. This indicates high resistance to corrosion at $0.5 \mathrm{M}$. The high chromium content which forms chromium oxide passivation on the surface of AISI 316 protects it initially. The $8.24 \%$ nickel contained in the AISI 316 also assists in providing resistance to uniform corrosion in moderate reducing environment of $\mathrm{HCl}$ at low concentrations. However, as the concentration of the $\mathrm{HCl}$ increases, the corrosion rates decrease. Both the chromium oxide and nickel were exposed that offered protection were destroyed by the acid which was responsible for increase in corrosion rates and also agreed to the findings of [27].

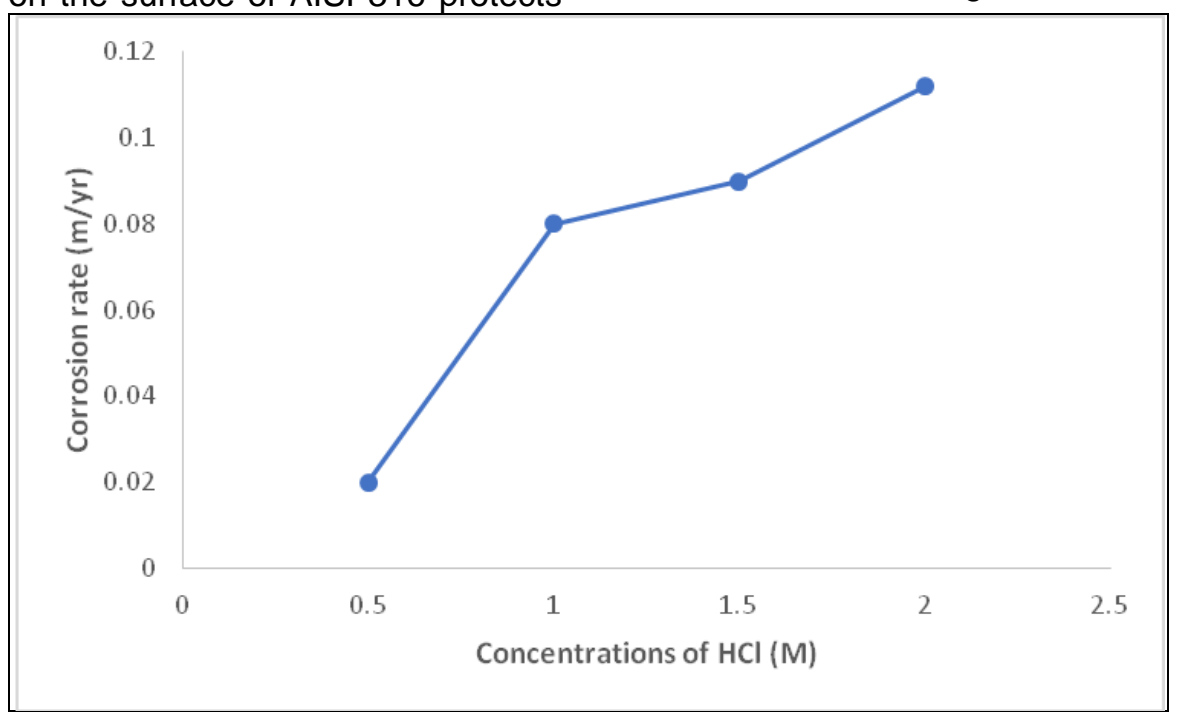

Figure 2. Variation of corrosion rate against concentration for AISI 316 immersed at different concentrations of $\mathrm{HCl}$

Slika 2. Varijacija brzine korozije u odnosu na koncentraciju za AISI 316 uronjenog u različitim koncentracijama $\mathrm{HCl}$

3.2.3. Effect of temperature on corrosion of AISI 316

Figure 3 showed the variation of corrosion rate against temperature for AISI 316 immersed in $\mathrm{HCl}$. From the table, there was an increase in corrosion rate as the temperature increases at the concentrations investigated. This is due to increased rate of dissolution process of AISI 316 of the metal surface at high temperature [28]. In an acidic solution the corrosion rate is related to temperature by the Arrhenius equation and the log of corrosion rate is a linear function of temperature which agreed with the findings of [29].

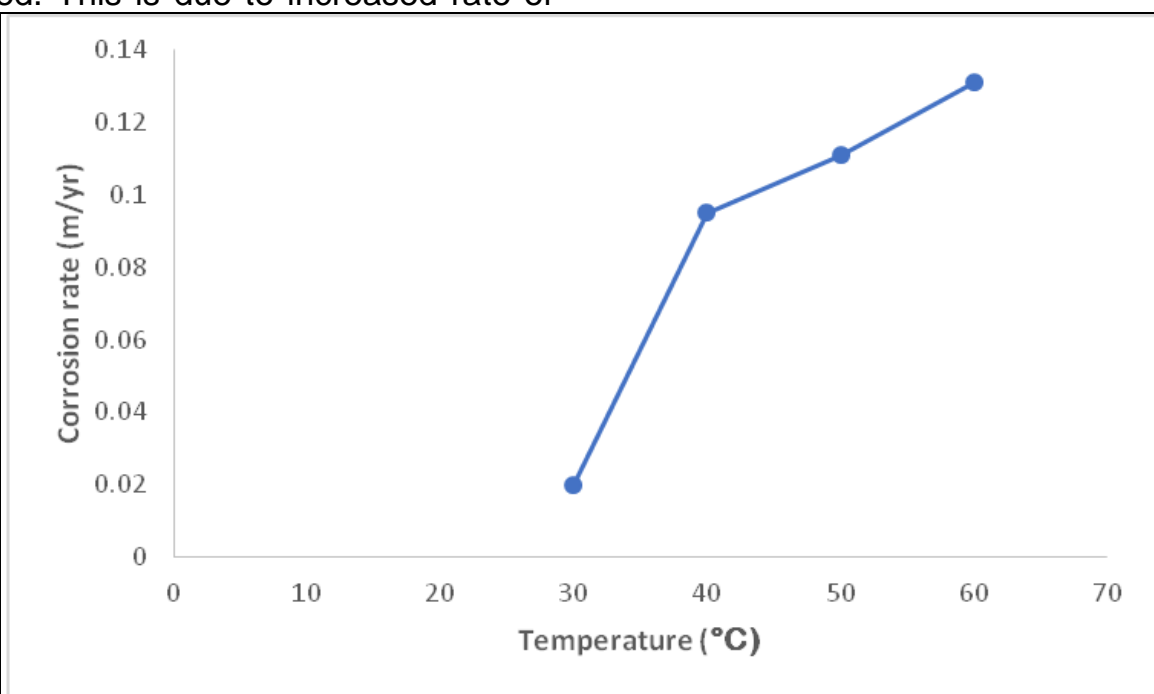

Figure 3. Variation of corrosion rate against temperature for AISI 316 immersed in $\mathrm{HCl}$

Slika 3. Varijacija brzine korozije u odnosu na temperaturu za AISI 316 uronjenog u $\mathrm{HCl}$ 


\subsection{Potentiodynamic polarization (Tafel) curves}

Potentiodynamic polarization curves obtained for different concentrations of the hydrochloric acid are given in figure 4. The potentiodynamic polarization studies revealed that the corrosion current density (Icorr) markedly increased with the increase in the concentration of the acid. However, the corrosion potential shifted to high negative values upon increase of the acid concentration. The values of anodic and cathodic Tafel slopes were changed indicating that this behaviour reflects the acid concentration ability to initiate pits formation to pits growths as the concentrations of acid increase from $0.5-2 \mathrm{M}$ on both anodic and cathodic sites. The behaviour reflects the acid ability to cause pits corrosion in AISI 316 on anodic and cathodic sites [24]. It was observed that with increase in concentration of the acid from 0.5 to $2 \mathrm{M}$, the maximum corrosion rate was observed for the concentration of $2 \mathrm{M}$ of the $\mathrm{HCl}[27,28]$.

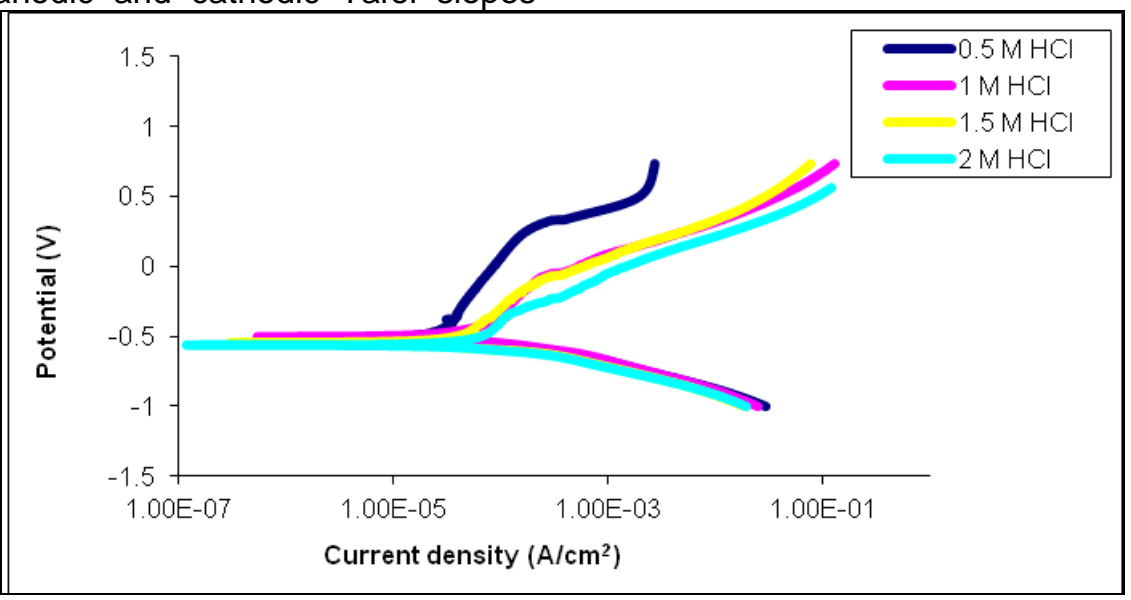

Figure 4. Potentiodynamic polarization curves for $\mathrm{AlSl}$ at various concentrations in $\mathrm{HCl}$ solutions at $30^{\circ} \mathrm{C}$

Slika 4. Potenciodinamičke polarizacione krive za AISI pri različitim koncentracijama u rastvorima $\mathrm{HCl}$ na $30^{\circ} \mathrm{C}$

\subsection{Surface Morphology of AISI 316 at Different concentrations}

The morphology of AISI 316 samples as-received and at different concentrations in hydrochloric acid solutions were presented in plates 1-5. Plate 1 presented the surface morphology of as-received.
Plate 2 showed samples in $0.5 \mathrm{M} \mathrm{HCl}$ solution, where pits initiation commenced which is often linked to the presence of local defects at the metal surface such as flaws in the oxide or segregation of alloying elements, presence of aggressive anions such as chlorides in the environment.

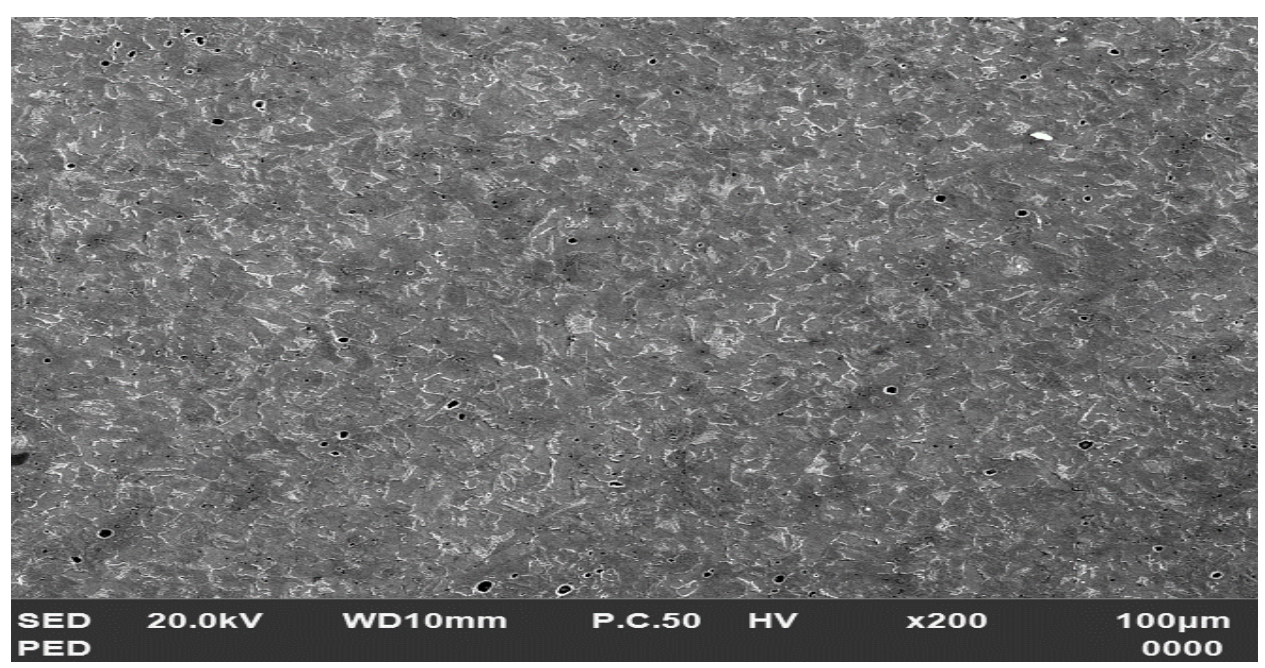

Plate 1. SEM microstructure of as-received AISI 316

Ploča 1. SEM mikrostruktura primljenog AISI 316 


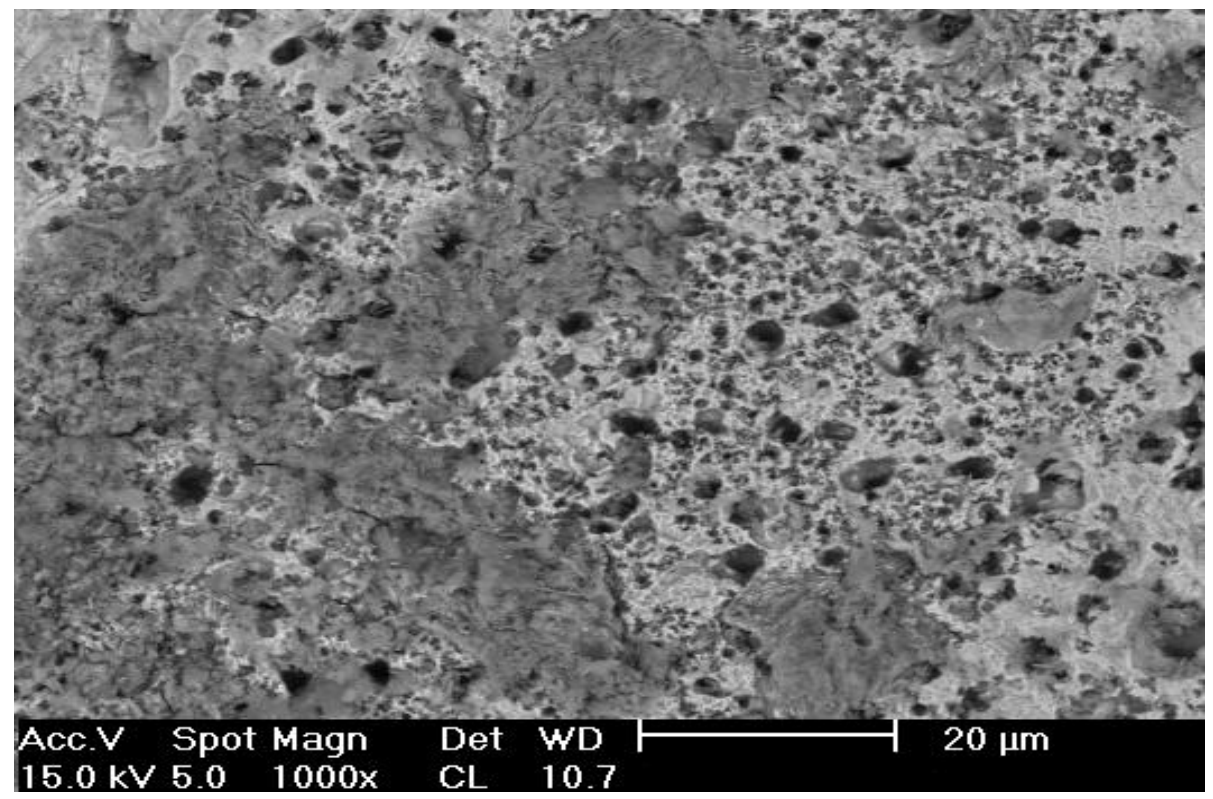

Plate 2. SEM microstructure of AISI 316 in $0.5 \mathrm{M} \mathrm{HCl}$

Ploča 2. SEM mikrostruktura AISI 316 u $0.5 \mathrm{M} \mathrm{HCl}$

Pit initiation occurs on the alloy surface passivated by an oxide film due to the damage caused by passivation of the electrolyte resulting in anodic reaction on the metal surface while the unexposed protective surrounding becomes the cathode leading to localized corrosion. Plates 3-5 showed the morphologies of AISI 316 in $\mathrm{HCl}$ at different concentrations of $1 \mathrm{M}, 1.5 \mathrm{M}$ and $2 \mathrm{M}$ respectively. At these concentrations, growth of pits increases as the concentrations of the acid increases and more pitted AISI 316 were seen especially in plates 4 and 5 . From the SEM evaluation, it is clear that as the concentrations of the hydrochloric acid increases, the corrosion resistance increases which confirmed the Tafel results obtained earlier and similar to the findings of $[2,4,6,8]$.

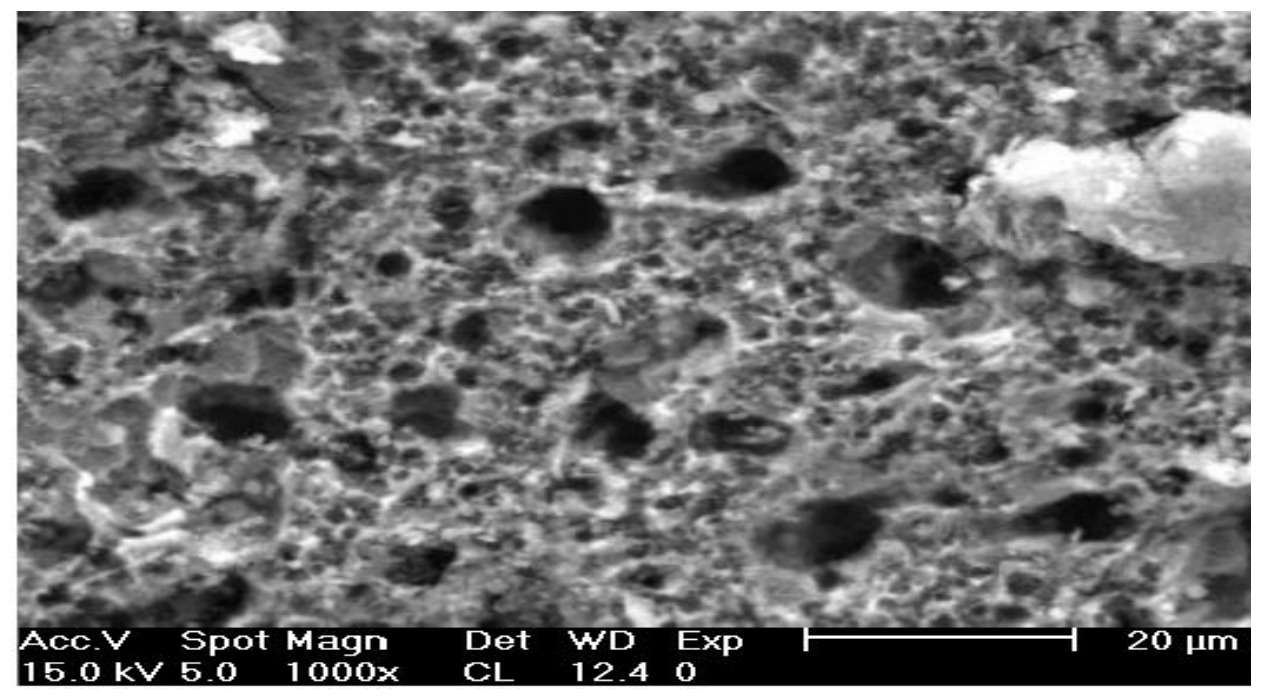

Plate 3. SEM microstructure of AISI 316 in $1 \mathrm{M} \mathrm{HCl}$

Ploča 3. SEM mikrostruktura AISI 316 u $1 \mathrm{M} \mathrm{HCl}$ 


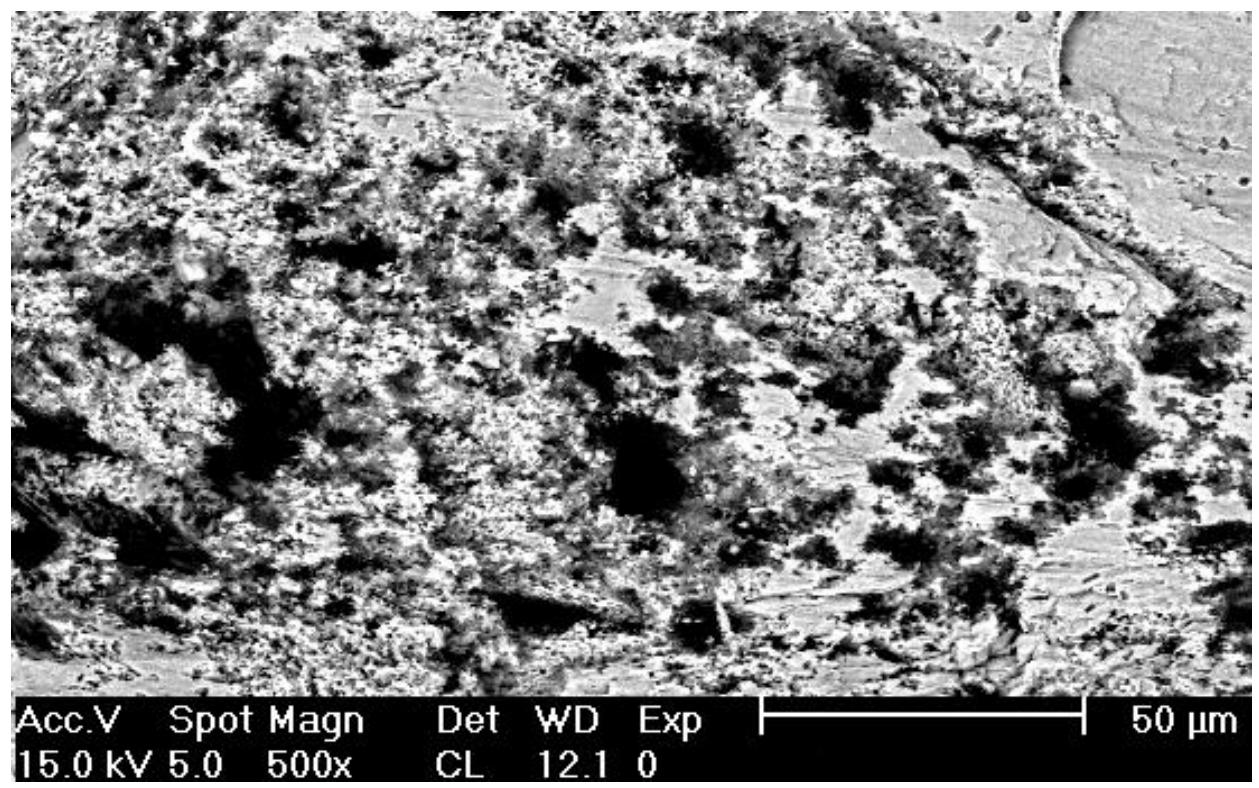

Plate 4. SEM microstructure of AISI 316 in $1.5 \mathrm{M} \mathrm{HCl}$

Ploča 4. SEM mikrostruktura AISI 316 u $1.5 \mathrm{M} \mathrm{HCl}$

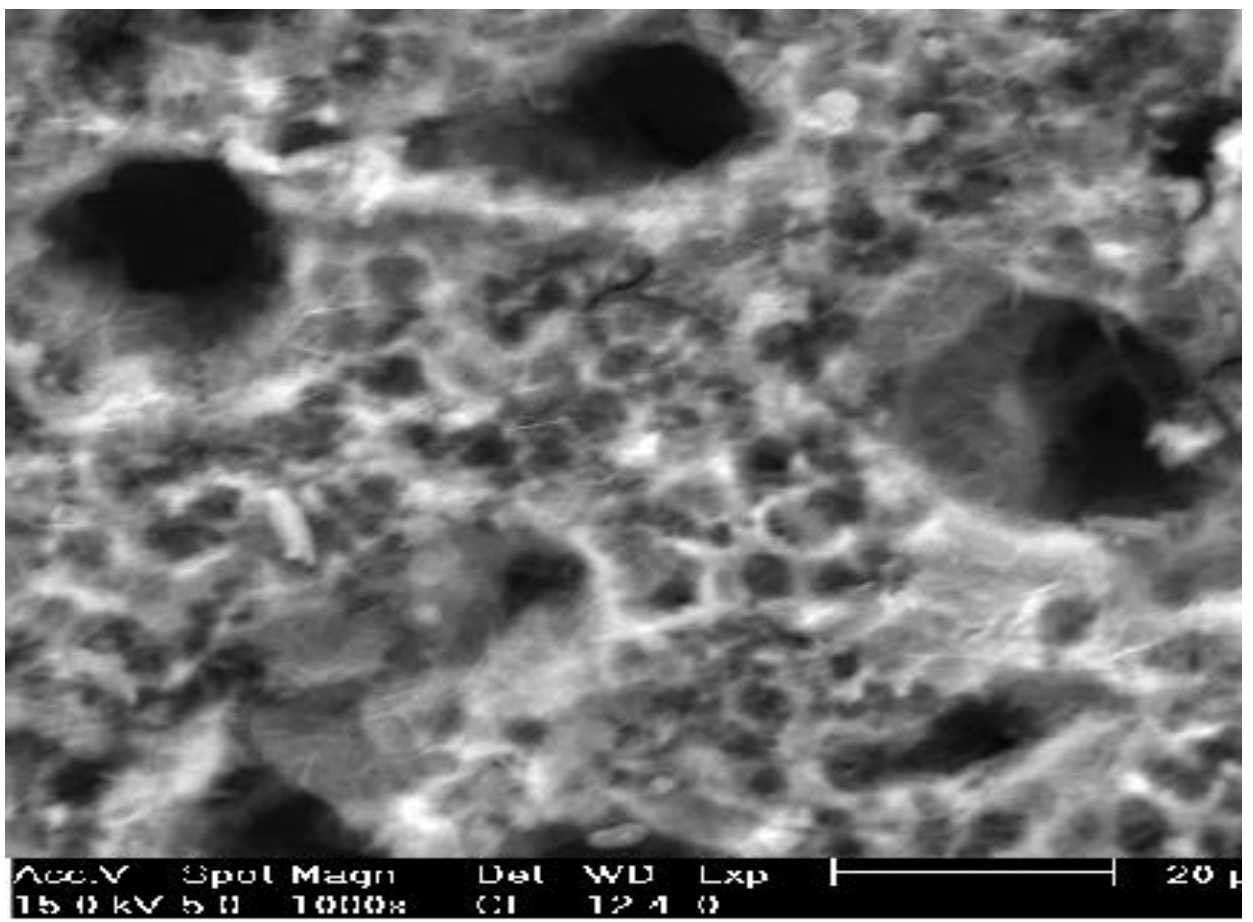

Plate 5. SEM microstructure of AISI 316 in $2 \mathrm{M} \mathrm{HCl}$

Ploča 5. SEM mikrostruktura AISI 316 u $2 \mathrm{M} \mathrm{HCl}$

\section{CONCLUSION}

The following conclusions can be drawn from the results obtained:

1. The corrosion rate decreased with increase in exposure time from day 1 to day 6.
2. The corrosion rate of the AISI 316 increased with increase in temperature and was subjected to pits corrosion.

3. From the Tafel graphs and characterization results, the rank of potential at various hydrochloric 
acid concentrations from the highest to the lowest were $0.5 \mathrm{M}, 1 \mathrm{M}, 1.5 \mathrm{M}$ and $2 \mathrm{M}$ with hydrochloric acid respectively. Therefore, the lowest corrosion resistance of AISI was at $0.5 \mathrm{M}$.

4. The degree of pits formation and growths increases with increase in acid concentrations of $\mathrm{HCl}$ and the results obtained from the Tafel and characterization are in good agreements.

\section{Acknowledgments}

The authors are thankful to the staff of Department of Metallurgical and Materials Engineering, University of Nigeria, Nsukka and Department of Chemical, Metallurgical and Materials Engineering, Tshwane University of Technology, Pretoria, South Africa.

\section{REFERENCES}

[1] M.Finšgar, J.Jackson (2014) Application of corrosion inhibitors for steels in acidic media for the oil and gas industry: A review, Corros. Sci., 86, 1741.

[2] M.D.Asaduzzaman, C.M.Mustafa, M.Islam (2011) Effects of concentration of sodium chloride solution on the pitting corrosion behavior of AISI-304L austenitic stainless steel, Chem. Indus Chem Eng. Quart., 17 (4), 477-48.

[3] B.Haryono (1998) Corrosion, MI and QA Team, Unocal Indonesia Company, Santan Terminal.

[4] A.Rustandi, B.Ramadhan, A.Fadhil, S.Setiawan (2016) Corrosion Behavior Comparison of Austenitic Stainless Steel 304l and 316I in Aqueous Sodium Chloride Solution by using Electrochemical Impedance Spectroscopy. Proceedings of ISER 39th Int. Conf., Bali, Indonesia.

[5] I.Y.Suleiman, V.S.Aigbodion, C.O.Obayi, K.Mu'azu (2019) Surface characterisation, corrosion and mechanical properties of polyester-polyester/snail shell powder coatings of steel pipeline for naval applications, Int J Adv Manuf Technol., 101, 24412447.

[6] P.R.Roberge (2008) Corrosion Engineering Principles and Practices, McGraw -Hill Int. Book Co., p.190- 294.

[7] M.Finšgar, S.Fassbender, F.Nicolini, I.Milošev (2009) Polyethyleneimine as a corrosion inhibitor for ASTM 420 stainless steel in near-neutral saline media, Corros. Sci., 51, 525-533.

[8] K.Darowicki (2004) Evaluation of pitting corrosion by means of dynamic electrochemical impedance spectroscopy", Science Direct, Electrochim Acta., 49., 2909-2918.

[9] I.Y.Suleiman, A.T.Mohammed, M.Z.Sirajo, S.R.Ochu (2018) Synergistic Effect and Statistical Model of Terminalia avicennioides as Anti-corrosion Inhibitor of Steel Pipelines in Acidic Environment, J Bio- and Tribo-Corros., 4(48), 1-9.
[10] N.Chaubey, D.K.Yadav, V.K.Singh, M.Quraishi (2017) A comparative study of leaves extracts for corrosion inhibition effect on aluminium alloy in alkaline medium, Ain Shams Eng. J., 8, 673-682.

[11] E.Poorqasemi, O.Abootalebi, M.Peikari, F.Haqdar (2009) Investigating accuracy of the Tafel extrapolation method in $\mathrm{HCl}$ solutions, Corros. Sci., 51, 1043-1054.

[12] E.Gileadi, E.Kirowa-Eisner (2005) Some observations concerning the Tafel equation and its relevance to charge transfer in corrosion, Corros. Sci., 47, 3068-3085.

[13] J.R.Scully (2000) Polarization resistance method for determination of instantaneous corrosion rates, Corros., 56, 199-218.

[14] U.Lotz, L. van Bodegom, C.Ouwehand (1991) The effect of type of oil or gas condensate on arbonic acid corrosion, Corros., 47, 635-645.

[15] Y.A.Albrimi, A.A.Addi, J.Douch, M.Hamdani, R. Souto (2016) Studies on the adsorption of heptamolybdate ions on aisi 304 stainless steel from acidic hcl solution for corrosion inhibition, Int. J Electrochem. Sci., 11, 385-397.

[16] F. Al-Nowaiser (2010) Corrosion inhibition of type 430 stainless steel in $\mathrm{HCl}$ solution by dipyridinium salts, King Abdulaziz Univ., 22, 89-100.

[17] A.M.Al-Turkustani (2010) Effect of Ajowan Seeds as Safe Inhibitor on the Corrosion of Steel in $2.0 \mathrm{M}$ Sulfuric Acid, Mod Appld Sci., 4 (10), 52-61.

[18] A.Singh, E.E.Ebenso, M.A.Quraishi (2012) Corrosion Inhibition of Carbon Steel in $\mathrm{HCl}$ Solution by Some Plant Extracts., Int J Corros., 34, 1-20.

[19] A.Singh, V.K.Singh, M.A.Quraishi (2010) Inhibition Effect of Environmentally Benign Kuchla (Strychnos Nuxvomica) Seed Extract on Corrosion of Ferritic stainless steel in Hydrochloric Acid Solution, Rasayan J Chem., 3(4), 811-824.

[20] H.Gerengi, I.Uygur, M.Solomon, M.Yildiz, H.Goksu (2016) Evaluation of the inhibitive effect of Diospyros kaki (Persimmon) leaves extract on St37 steel corrosion in acid medium, Sust Chem Pharm., 4, 57-66.

[21] E.Ikama, U.Uwah Benedict, I.Ugi Alexander, E. Ikeuba Kokomma (2013) Evaluation of the inhibitive action of eco-friendly benign costus afer stem extract on the corrosion of ferritic stainless steel in 5 M HCL solution, Int J Develop Sust., 2(4), 1970 1981

[22] A.C.lyasara, J.E.O.Ovri (2013) Corrosion Inhibition of Stainless Steel (314I) Using Molasses, Int J Eng Sci., 2, 346-352.

[23] M.Babutzka, A.Heyn, P.Rosemann (2018) Influence of austenitizing and tempering on the corrosion behavior and sensitization of martensitic stainless steel X50CrMoV15, Maters Corros., 24, 1-12.

[24] C.Mary Anbarasi, S.Rajendran (2011) Corrosion behaviour of carbon steel in Hexane Sulphonicacid. Int J Adves Eng, Sci Technol, 1(1), 22-29.

[25] M.Hazwan Hussin, M.Jain Kassim (2010) Electrochemical Studies of Ferritic stainless steel 
Corrosion Inhibition in Aqueous Solution by Uncaria gambir Extract, J Phys Sci., 21(1), 1-13.

[26] M.Naghizadeh, D.Nakhaie, M.Zakeri, M.Moayed (2015) The effect of dichromate ion on the pitting corrosion of AISI 316 stainless steel Part II: Pit initiation and transition to stability, Corros. Sci., 94, 420-427.

[27] C.C.Nathan (1962) Corrosion Inhibitors Edited By Betz Laboratories, Houston, Texas.
[28] T.David, T.James (1998) Corrosion science and technology, CRC Press, Florida.

[29] N.D.Tomashov, G.P.Chernova (1967) Passivity and Protection of Metals against Corrosion. Plenum Press, New York.

[30] S. Kadry (2008) Corrosion analysis of stainless steel, Eur. J. Scientific Res., 22, 508-516.

\section{IZVOD}

\section{KARAKTERIZACIJA I KOROZIJSKO PONAŠANJE AISI 316 U HIDROHLORNOJ OKOLINI PRI RAZLIČITIM KONCENTRACIJAMA}

Ispitivane su karakteristike i korozijsko ponašanje vrsta austenitnog nerđajućeg čelika (AISI 316) u različitim koncentracijama rastvora hlorovodonične kiseline u odnosu na njegovu korozijsku otpornost. Za istraživanje su korišćeni gravimetrijski gubitak težine i potenciodinamička polarizacija. AISI 316 je okarakterisan pomoću rendgenski fluorescentnog analizatora (KSRF). Karakterizacija uzoraka pre i posle korozijskog testa u različitim koncentracijama izvršena je pomoću skenirajuće elektronske mikroskopije (SEM). Temperatura, koncentracija kiseline i vreme varirali su u rasponu od $30-60^{\circ} \mathrm{C}$ u intervalu od $10^{\circ} \mathrm{C}, 0,5-2 \mathrm{M}$ na intervalu $0,5 \mathrm{M}$ i 1 do 6 dana u intervalu od jednog dana, respektivno. Pomoću KSRF otkriveni su neki važni elementi u AISI 316, kao što su (Cr, Ni, Mn, Si, C, S, P itd) koji su potvrdili tačnost materijala AISI 316. Rezultati gubitka težine otkrili su da se stopa korozije smanjivala s povećanjem vremena izlaganja od jedan do šestog dana. Brzina korozije AISI 316 povećavala se sa porastom temperature, teškim za formiranje rupa, i rasla je sa povećanjem koncentracije kiseline od 0,5 - 2M. Brzina korozije AISI 316 raste sa povećanjem koncentracije kiseline. Rezultati Tafelih krivi, takođe, su otkrili da su i anodna i katodna mesta pomerena sa najmanjom otpornošću na koroziju koja se pojavljuje pri 0,5M HCl. SEM uzorka u prisustvu kiseline otkrio je formiranje jama i narasle površine AISI 316. Rezultati dobijeni merenjem gubitka težine, Tafel-om i karakterizacijom su se takođe dobro slagali. Ključne reči: Austenitni AISI 316, karakterizacija, ponašanje korozije, pitting, otpornost, rastvor $\mathrm{HCl}$, Tafel.

Naučni rad

Rad primljen: 15. 06. 2020.

Rad prihvaćen: 10. 07. 2020.

Rad je dostupan na sajtu: www.idk.org.rs/casopis

(C) 2020 Authors. Published by Engineering Society for Corrosion. This article is an open access article distributed under the terms and conditions of the Creative Commons Attribution 4.0 International license (https://creativecommons.org/licenses/by/4.0/) 